The Foreign Office announces the publication and distribution of the first volumes of the "FIAT Review of German Science", compiled by German experts under the direction of the British, American and French Field Intelligence Agencies (Technical). The Review is written in German and covers fundamental research in pure science during the years 1939-46. By agreement between the British, American and. French agencies, the first printing is a restricted edition for official distribution between the three Allies and U.N.E.S.C.O. The British share of about 250 sets will be issued to Government and other bodies within the Commonwealth, to universities and medical schools and to the libraries of certain learned and professional societies. It is hoped that the edition will be completed within the next six months. The Allied edition of the FIAT Review will be followed by a German edition. The latter, also printed in German, will be published by Dieterich'sche Verlagsbuchhandlung, Wiesbaden, Germany, and will be obtainable through normal trade channels. It is understood that volumes will not be sold separately but only in sets comprising the titles under the headings physics, chemistry, mathematics, medicine, biology and sciences of the earth.

\section{Eclipse Observations for Geodesy}

IT is now possible to amplify the brief reference in Nature of February 7 (p. 196) to the application to geodesy of the times of contact to be observed at different stations on the track of the annular eclipse of May 8-9, 1948. The first suggestion that such observations might provide information as to the earth's shape over areas where geodetic triangulation is impracticable was made by Mr. G. E. Barton (Mon. Not. Roy. Ast. Soc., 64, 105; 1926). His observations at Benkoelen at the eclipse of January 14, 1926, were spoilt by an unfortunate accident, but the idea was afterwards adopted, and expeditions from a number of countries used improved methods of time determination of such observations at the total eclipses of 1945 and 1947 by parties well separated in longitude. For the annular eclipse of next May, the National Geographic Society of the United States has prepared an elaborate scheme of observations at seven ground stations from Mergui in southern Burma to Kiska in the Aleutians. These will be supplemented by observations from aeroplanes of the U.S. Air Force; photographs of the eclipse will be taken from above the clouds from positions determ. ined by short-range radar navigational methods.

The U.S. Army's Map Service, Engineer and Signal Corps, the U.S. Navy, Air Force, Bureau of Standards, Coast and Geodetic Survey and State Department will co-operate with the National Geographic Society in the scheme. The leaders of the different parties are to be as follows : at Mergin, Mr. E. A. Halbach; at Bangkok, Prof. Charles H. Smiley with Prof. C. W. Miller; at Wu-K'ang, China, Father Francis J. Heyden with Dr. V. C. Chang; at Cho-nan, Korea, Dr. George van Biesbroeck; at Kiska and Adak, Lieut.-Cmdr. Clarence R. Reed and Mr. Clarence A. Shelton; while at the Japanese island of Rebun Jima there will be a Japanese astronomer selected by Prof. Hagihara, of the Tokyo Observatory. This marks a welcome move towards international co-operation in science between Japan and the United States. Measurements of the times of contact will be made by photographing the eclipse on $35-\mathrm{mm}$. sound motion pictures which will record the ticks of a chronometer on the sound track. The chronometers will be checked and rated from radio time-signals. The techniques which make these observations practicable have been developed to a high degree of efficiency in the last twelve years.

\section{Journal of the Institute of Navigation}

THE recently founded Institute of Navigation, the headquarters of which for the present are at the Royal Geographical Society, Kensington Gore, London, S.W.7, has issued the first number of its quarterly Journal (London: J. Murray. 25s. per annum). The object of the Institute is to unite those interested in the science and art of navigation, both by sea and in the air. Fellows are those who are either professional navigators or who have made outstanding contributions to the science of navigation; members are those who are generally interested. The Astronomer Royal is president of the Institute, and he has contributed to the new Journal an introductory address on the development of navigation. Other articles are on radio aids to navigation, consol, pressure pattern flying and many other topics. The new ocean weather service also finds a place: its ships, equipment and tasks are explained. The Journal promises to be a useful addition to the list of scientific periodicals.

\section{Plant Disease Charts}

Plant Protectron, Ltd., has recently issued two useful wall charts illustrating common and important crop diseases and pests. Both charts are beautifully produced in colour, depicting parts of the plants diseased and the insects where such are concerned. One is entitled "Some Crop Pests and Diseases" and illustrates and describes the following: tomato blight, celery leaf-spot, celery leaf miner, cabbage white caterpillar, black aphis, potato blight, carrot fly, turnip flea beetle, onion mildew, chocolate spot of broad bean, mole cricket, locust, pea and bean weevil, leatherjacket, wireworm, cutworm. The other, "Pests and Diseases of Apples", deals with brown rot, woolly aphis, sucker, apple and pear scab, winter and March moths, sawfly, capsid bug, codling moth, apple blossom weevil and apple mildew. Methods of prevention or protection are shortly described in each case. These wall charts will be a valuable visual aid for schools and agricultural colleges and institutes, which can obtain copies free of charge from Plant Protection, Ltd., Yalding, Kent.

\section{Biology of Lice}

A SECOND edition of the booklet entitled "Lice" by Dr. John Smart, published as Economic Series No. 2A by the British Museum (Natural History) has recently appeared (British Museum (Natural History), London, S.W.7, 1948. 9d.). It deals with the incidence, development and habits of lice affecting man and the best methods for controlling these pests. During the six years interval that has elapsed since the appearance of the first edition of this booklet, much new knowledge concerning lice has come to hand, especially relative to control measures acquired during the War. Information on these and other features are incorporated in the new edition.

\section{International Conference on the Physics of Metals}

THE Netherlands Physical Society is organising an international conference on the physics of metals, to be held at Amsterdam during July 12-18, after the Assembly of the International Union of Pure and Applied Physics. The provisional programme 